Journal of Economics and Behavioral Studies

Vol. 6, No. 7, pp. 551-560, July 2014 (ISSN: 2220-6140)

\title{
Microfinance, Poverty Alleviation and Sustainability: Towards a New Micro-Finance Model for Zimbabwe
}

\author{
Stephen Mago \\ University of Fort Hare, South Africa \\ stepmago@gmail.com
}

\begin{abstract}
The main aim of this paper is to propose the development of a new microfinance model that can approximate sustainability in Zimbabwe. The secondary purpose is to find out whether the same model can be replicated in other developing countries. The paper adopted a mixed methodology. A crosssectional data collection method was preferred because data was collected during the time of high volatility in the country. Questionnaires, interview schedules were combined to collect data from villagers involved in microfinance programmes. Data were collected from 250 households in the Masvingo rural district area of Zimbabwe. The findings show that the two polar models are biased, hence the need for the 'middle of the road approach'/'hybrid model' for the provision of microfinance services to the poor in order to achieve the twin objectives of poverty alleviation and sustainability. The paper is limited to a Masvingo district of Zimbabwe, thus replication could become a challenge. This article attempts to develop a 'middle of the road' model for microfinance in Zimbabwe. According to our knowledge, there is no study that has attempted to do the same.
\end{abstract}

Keywords: Microfinance, poverty alleviation, sustainable development, microfinance model, Zimbabwe.

\section{Introduction}

This paper's task is the development of a micro-finance model that is suitable for the Zimbabwean socioeconomic environment-with possibility of replicating it in other contexts. Based on the literature, as well as our findings and analysis, the paper proposes to develop a microfinance model for the Zimbabwean context. The two main models used to define the aim and purpose of microfinance is the Poverty Lending Approach (PLA) and Financial Systems Approach (FSA). The study identified gaps that exist in the major models used in the implementation of microfinance as a poverty alleviation strategy. It should however be cautioned that models are not static tools but they change with time as other variables in the economy shift. In Bangladesh for example, the use of the popular Grameen Bank (GB) model is not static because it has undergone major adjustments. The Association for Social Advancement (ASA) also in Bangladesh developed a set of different procedures for microfinance delivery that were different from the GB model (Ahmed, 2010). It would neither be feasible nor progressive to develop a static or fixed model. The anticipated model should be flexible to the broader socio-political and economic environment so as to allow for innovative changes and flexible policy formulation and implementation.

Two polar models explain microfinance as a poverty alleviation strategy. These are the Poverty Lending (PLA) and Financial Systems Approach (FSA). Microfinance debates focus on poverty alleviation and sustainability but there seems to be a trade-off between the twin objectives. Consequently, the poverty and sustainability camps have emerged with influence emanating from the two schools of thought about the provision and impact of microfinance. Microfinance is about the provision of a range of financial services to the poor and low income groups of society (Ahmed, 2010; Zhang and Wong, 2014). The point of departure shall be the poverty lending approach/model (PLA), and the financial systems approach/model (FSA). This is followed by a more moderated approach that was propounded by Gulli in 1998. Gulli's argument comes as a critique of the two polar models thus it gives a basis for the crafting of an alternative or middle of the road model. An analysis of these models will give direction towards the development of a new or alternative model for microfinance in Zimbabwe. Development of an alternative model will give a contribution to the microfinance industry that is in urgent need of achieving the poverty alleviation objective in a sustainable way. 


\section{Theoretical Analysis}

The Poverty Lending Approach (PLA): The poverty lending approach is an altruistic (philanthropic) model for the provision of microfinance to the poor. The objective is to provide subsidized loans to the poor so as to alleviate poverty. Supply-leading theories inform this line of thought, hence the need to have the government as the main player in the supply of funds to the poor for them to be included into the financial system (Robinson, 2001; 2002; Zhang and Wong, 2014). Unfortunately, the provision of finance by governments has had a poor success rate in most countries. In some cases, the performance has been dismal, with the fiscus losing lots of money to programs that are not sustainable. A case in point is the loss of funds experienced by Agricultural Bank of Zimbabwe (AGRIBANK). The financial institution bankrolled the farming projects of 'new farmers' ${ }^{1}$ after the year 2000 'fast track' land reform program in Zimbabwe (UNDP, 2008). Most farmers were given loans to buy inputs and develop their new farms. The majority failed to repay the loans because they did not direct them towards farm production but used them for other purposes. This explains the fungibility problem that is associated with loans. Since AGRIBANK is a government bank, the loans were cancelled after government instruction and the bank registered losses (UNDP, 2008). These losses were attributed to loan non-repayment by a bulk of the new farmers. The PLA suffers from sustainability challenges. Since the underlying assumptions are that the poor cannot afford market interest rates on loans, then government or donor funds should always be available to assist the poor. Robinson $(2001 ; 2002)$ laments that the model is not affordable since large amounts of money are needed to provide subsidized credit. The burden of subsidizing microfinance activities leaves the sustainability question unanswered and it remains problematic to execute the PLA model as a sustainable poverty alleviation strategy. The financial systems approach stands on the other polar side of microfinance discourse.

The Financial Systems Approach (FSA): The other school of thought is about following the financial systems approach (FSA) in the provision of microfinance for poverty alleviation. The FSA is based on the assumption that the poor can afford market rates, full recovery of costs should be achieved, institutional sustainability is core and government role should be limited to regulation. It emphasizes sustainability at the expense of poverty alleviation among the poor. It is seen as a 'mission drift'2 from the main objective of microfinance, which is poverty alleviation. When Yunus, the renowned economist in microfinance, rekindled the microfinance idea in 1976, the main focus was poverty alleviation (Ahmed, 2010; Zhang and Wang, 2014). This means that we need a model that endeavors to address the twin objectives of poverty alleviation and sustainability in microfinance. Thus, looking at both institutional and program or project sustainability. A critique of the above models is necessary to build a foundation for the new model.

Gulli's Critique: Academics, development practitioners, development economists, and planning authorities have not rested to seek for a middle of the road microfinance model that brings together the poverty and sustainability microfinance camps. The PLA and FSA models are more concerned with money in their approaches which compromises sustainability hence facing criticism from scholars such as Gulli (1998). Sherraden (1991) further notes that welfare policy is pre-occupied with protection of the poor from an income perspective instead of seeking to protect them through empowerment. Consequently, sustainability is compromised. Sustainability is viewed as a key element in the achievement of poverty alleviation through microfinance. Therefore, there is need for research to lead to the development of a new microfinance model that can achieve the twin objectives of poverty alleviation and sustainability. Poverty alleviation is one of the major objectives of governments and other stakeholders, but the challenge centers on dealing with the problem of poverty in a sustainable way. This study reiterates that development history shows that the provision of credit by governments proved to be a failure in many countries (Adams et al., 1984). Traditional financiers are on the other hand, not interested because of sustainability challenges. The main argument being that microfinance is not profitable because of very high transaction costs. At the same time, some private money lenders charge very high (usurious or extortionate) interest rates, making the poor people to be trapped in debt. This argument and the commonplace discourse around microfinance, calls for the development of an alternative model that addresses the twin objectives (i.e. poverty alleviation and sustainability).

\footnotetext{
1 "New farmers" refers to all the farmers that acquired farm land during the Zimbabwean 'fast track' land reform program that started in year 2000.

${ }^{2}$ Mission drift is a term used to mean departing from originally set objectives or focus. See Hishigsuren (2007) for discussion on mission drift in microfinance.
} 
Gulli suggests a "contingency approach" to microfinance provision. She argues that the question should not be about whether or not microfinance is an important strategy for poverty alleviation. The issue should then be about how, to what degree and under which conditions microfinance can be contributory to poverty alleviation. Gulli's argument borrows from Mahajan and Dichter's proposition of an alternative strategy for livelihood promotion in their paper entitled "A Contingency Approach to Enterprise Promotion" (1998). They opine that enterprise development can be achieved by looking at the bottlenecks that face the organizations. The bottlenecks should then be targeted as working points, or rather weak points. They gave an example that, where credit is a constraint then minimalist credit would be sufficient rather than supplying a wide range of services that may not be required at a particular point in time. In some cases, they argue, credit may not be the main constraint so the constraints such as skills, markets and infrastructure should be provided. Unfortunately, Gulli did not fully develop the approach. Therefore, this study argues that the contingency approach is an intricate model that requires the development of a 'what if' spreadsheet to provide answers for the different scenarios resulting from the need of resources. The approach does not realize the need to look at the livelihoods of the poor in order to develop a link between them and microfinance hence achieving both poverty alleviation and sustainability.

Efforts to provide microfinance services to the benefit of poor people have been scuttled in the majority of cases because of lack of a model that has a focus on providing a linkage between finance and the poor people's livelihoods. As indicated earlier, the principal objective of microfinance is the provision of finance among the poor for poverty alleviation. Most microfinance projects have been very successful in other countries but have performed dismally in others. This leaves a question on replicability of models such as the Grameen Model of Bangladesh. The Grameen Model has survived a number of environments but has also faced serious challenges in others, especially Africa. In Zimbabwe for instance, the Masvingo Credit against Poverty (M-CAP) replicated the Grameen Bank Model in providing credit to the poor. MCAP started its operations from a seed funding provided by the Grameen Bank of Bangladesh hence the need to use the Grameen Model (CAP Business Plan, 1999). The organization faced a number of challenges especially during the Zimbabwean economic crisis, the main one being sustainability. The survival of the organization could have been achieved had it followed sustainable strategies to the poverty alleviation efforts. This implies that there is need for the development of a model or models that suit other environments for the propagation of the microfinance strategy in the world. This paper suggests that, for microfinance to have a 'durable' impact, it should borrow from the sustainable livelihoods perspective. The new model is discussed below within the Sustainable Livelihoods Approach (SLA) context. It suggests a strong linkage between microfinance and livelihoods for a 'durable' or robust and sustainable solution to poverty in the rural areas since the main challenge is the sustainability of poverty alleviation programs.

The Sustainable Livelihoods (SL) Approach: The need for a sustainable microfinance model can never be overemphasized. The sustainable livelihoods approach (SLA) is not a microfinance model in the true sense of the PLA and FSA. But there are interesting elements that we can borrow from SLA towards a new model. The new model should therefore endeavor to achieve the twin objectives of poverty alleviation and sustainability. Sustainability is a long standing challenge in microfinance hence the need to borrow sustainability elements from the SLA. It is anticipated that borrowing from the SLA would strengthen microfinance hence achieving the objectives through a hybrid microfinance model. In other words, a livelihood refers to household outcomes that are necessary for a living. Our survey findings established that assets, income and savings are the main household outcomes that have a strong relationship with microfinance. Capabilities and assets are central to the survival of the people in the rural areas, hence the need for a livelihood diversification. "Livelihoods diversification refers to attempts by individuals or households to find new ways to raise incomes and reduce risks." (Hussein and Nelson, 2004:3). Diversification in this context involves the people undertaking income generation activities that are both on-farm and non-farm. Livelihoods diversification therefore makes people to have a wider coping space for poverty alleviation. Access to financial resources (i.e. microfinance) by people in the rural areas necessitates livelihoods diversification hence the need for a strong link between rural microfinance and livelihoods.

The sustainable livelihoods (SL) approach is listed as an idea of the mid 1980s to 2000s. It was "widely deployed as a guiding principle for rural development practice" (Ellis and Biggs, 2001:438) during this period. Cahn's assertion strengthens the need to have access and entitlement promoted through the provision of financial resources which are the main lubricant to business development and innovation. 
Poor people are innovative as displayed by the way they survive the difficult situations. They develop special coping strategies in the event of problems, but they lack finance to sharpen their competitive edges. According to Fouracre (2001:1), "a policy of sustainable rural livelihoods focuses not on the needs of the rural poor, but rather, builds on the existing assets of the poor, both at the village and individuals level." The same is echoed by Sherraden (1991) and Birdsall and Londono (1997). Failure to identify opportunities presented to the poor in the rural areas makes them to remain poor (i.e. they become underpowered to climb out of poverty). The use of previous rural development interventions has in many instances failed to maximize rural opportunities. Sa-Dhan (2003) posits that current strategies should facilitate better-targeted poverty-alleviation interventions. Cahn (2002) points out that the sustainable livelihoods approach focuses on what people have rather than what people do not have. Livelihood strategies and activities may include farming, labour, non-farm income enterprises and household maintenance activities meant to achieve better livelihood outcomes. These strategies can be promoted by providing financial resources to the poor hence the need for a strong link between microfinance and livelihoods.

Since the approach incorporates participation, it makes people to have ownership of the development ideas. This approach encourages local people to be innovative and to indulge in various sustainable projects. The SL approach also recognizes that multiple actors (private, public, NGOs and communities) are important thus widening the range of potential partners (Sa-Dhan, 2003; Zhang and Wong, 2014). Furthermore, Sa-Dhan states that the SL approach stresses the importance of policies at macro-level and institutions. If well placed, they promote livelihoods options of poor people. There is also need for macromicro level policy articulation which is important for strengthening grassroots development efforts. Microfinance is a micro-level policy intervention that could be deliberately linked or coupled to sustainable livelihoods programs for poverty alleviation. However, Cahn (2002) states that sustainable livelihoods approach is still evolving and further benefits and disadvantages will emerge over time. Linking the sustainable livelihoods with microfinance is likely to develop a strong hybrid model that is both analytical and developmental. Microfinance will act as a lubricant to the livelihoods strategies that are presented by the sustainable livelihoods framework.

At the centre of the sustainable livelihoods approach is the framework on asset vulnerability. Asset ownership empowers the poor to control their own lives. The livelihoods concept combines assets and activities that generate viable livelihood strategies for rural families (Soussan et al., 2000). The sustainable livelihoods framework helps practitioners to understand the reality of the poor and the complexity of rural life. The importance of adopting the sustainable livelihoods approach is to alleviate poverty and to unlock opportunities for the poor. The framework helps the voices of the poor to be heard as they make their own decisions. The poor should have ownership of their decisions (Chambers, 1983). Microfinance empowers the poor by putting them in a position to make individual and group decisions. We discovered from the study survey that microfinance participants improved their decision making because of interaction during group meetings. As they engage in business ventures, they also improve on their individual decision making which they own.

Figure 1: Sustainable Livelihoods Framework

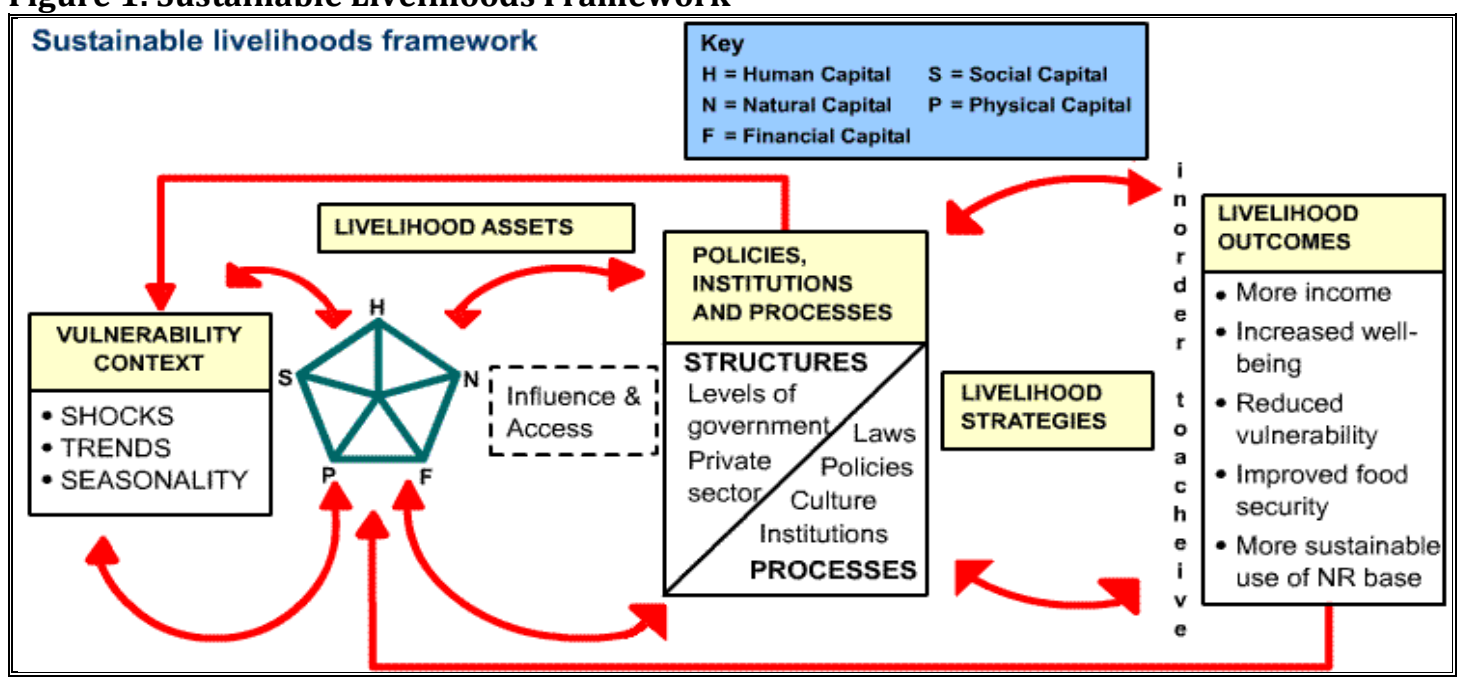


Key: $\mathbf{H}=$ Human Capital $\mathbf{N}=$ Natural Capital $\mathbf{F}=$ Financial Capital $\mathbf{S}=$ Social Capital $\mathbf{P}=$ Physical Capital Figure 1 above provides a framework that helps to trace the inter-connections found between various aspects of people's livelihoods (Soussana et al., 2000). The pentagon box in the diagram shows resources needed by households, which are H (Human capital); (P) Physical capital; S (social capital); F (financial capital) (F) and N (Natural capital). These are the 'big five' of the resources that represent the capabilities and assets of households. As depicted in the diagram, rural people face challenges from external forces that include shocks, seasonality and stress, trends, context and vulnerability. The sustainable livelihoods approach states that the poor people should use livelihood strategies (coping strategies) to achieve positive livelihoods outcomes so as to cope with the shocks and emergencies (Ellis and Biggs, 2001). The rural people can also benefit from the natural resources that surround them. See Khanya (2001) in Hussein (2002) for a more comprehensive SL framework. It should also be noted that different development agencies have developed sustainable livelihoods frameworks in different shapes but explaining the central issues of livelihoods For instance, CARE International's framework.

While Turton (2000) stresses that people have little control over critical trends and shocks that affect their livelihoods, there are positive and negative factors that importantly shape the rural development. For example, positive trends that promote rural development include building of roads, communication networks, infrastructure, schools and hospitals. These trends contribute towards poverty alleviation in a variety of ways. Identified negative trends that discourage rural development include lack of public safety nets for the poor, frequent health shocks such as cholera outbreaks, unpredictable climate and unmanaged exploitation of natural resources. These trends could be strengthened through the provision of microfinance to the poor in the rural areas. A strong link between microfinance and livelihoods could be afforded so as to build the capacity of the rural poor in dealing with vulnerability contexts for positive livelihood outcomes.

\section{Microfinance and Livelihoods}

Poverty alleviation in this regard needs to be concerned with the understanding of conditions of the poor in rural areas. Sa-Dhan (2003) highlights that the problems of the poor require a holistic view of their conditions and they should be addressed in the wider social and economic context. The new model then tries to place microfinance in the 'holistic picture' of alleviating poverty in the rural areas. Microfinance might have a greater impact if the linkage with livelihoods is established and strengthened. The new model is developed on the premise of this gap that has not been identified by previous researchers and academics. The identified gap shows the lack of emphasis or linkage between microfinance and livelihoods in rural development and poverty alleviation. According to our knowledge, there is no researcher that has developed a model linking microfinance to livelihoods. The results also show that the impact of microfinance on assets, income and savings can be strengthened by linking them with the notion of livelihoods.

Vulnerability context: Vulnerability refers to the environment that is external to where people exist (DFID, 1999). Trends, shocks (e.g. floods, storms, cyclones, droughts, political instability, diseases, and deaths) and seasonality (e.g. agricultural seasons, weather conditions, prices, health changes, employment opportunities etc) fundamentally affect the assets that are available to the vulnerable poor. Negative trends will then impact badly on the livelihoods of the poor leading to hardships. This paper suggests that the vulnerability context can be managed through the provision of microfinance resources. These have the capability of smoothening consumption patterns. DFID (1999) states that the main aim of the sustainable livelihoods approach is to support people in asset mobilization. DFID further stresses that increasing people's access to suitable financial services helps to reduce vulnerability. Therefore, the need for rural microfinance is emphasized by DFID. Placing microfinance in the SL framework enhances people to utilize it as a buffer to shocks and for the promotion of livelihoods diversification.

Livelihood Assets and Microfinance: As mentioned above, the capital assets are crucial to the achievement of desired livelihood outcomes. The key 'capitals' ${ }^{3}$ are financial, human, social, natural and physical. An inter-relationship exists among assets, with microfinance fitting in the interplay. The

\footnotetext{
${ }^{3}$ The term 'capital' is used to designate assets although in strict economic sense, not all assets are capital stocks.
} 
importance of assets is emphasized by Moser and Dani (2008:5) who suggest that "assets are the resource endowments and capabilities that sustain and enhance people's livelihoods." The same was emphasized by the research results. They help them to accumulate further assets for resilience to external shocks. The notion of capabilities brings to our minds popular capabilities and freedoms that are necessary for any poverty alleviation intervention.

Table 1: Assets

\begin{tabular}{ll}
\hline Assets & Examples \\
\hline Financial & Savings, Credit, Remittances, Pensions. \\
Human & Skills, Knowledge, Information, Ability to work, Health. \\
Social & Networks, Groups, Trust and reciprocity, Access to wider institutions of society (an \\
& intangible asset). \\
Natural & Land, Water, Wildlife, Biodiversity, Environment (stocks of environmentally provided \\
& assets-God given resources). \\
Physical & Transport, Shelter, Water, Energy, communication and production equipment (aka \\
& produced or man-made capital).
\end{tabular}

Source: Rakodi (2002:11); Moser and Dani (2008:50) and modified by author ${ }^{4}$.

The poor in the rural areas of Zimbabwe have land, their labour, knowledge and skills, friends and families, health and other natural resources around them. Land is one on the important assets of the rural people in Zimbabwe. For this study, the valuation of land as an asset was not done because of the instabilities around the land issue. Literature and empirical work show that the demand for finance capital by the people is highly unmet. The supply of microfinance is far less than the demand so there are no monetary resources to allow the exploitation of opportunities that are available in form of other capital assets. It is commonplace that urban economies are highly monetarised than rural economies, making it easier to access finance in the urban centers than in rural areas. This implies that the livelihood strategies by the poor in the rural areas need to be supported through the provision of finance, in this case, rural microfinance. Results demonstrated that microfinance has a positive impact on assets; income and savings. It also strengthens the 'big five' capitals as illustrated in figure 2 below.

\section{Figure 1: Livelihoods Pentagon}

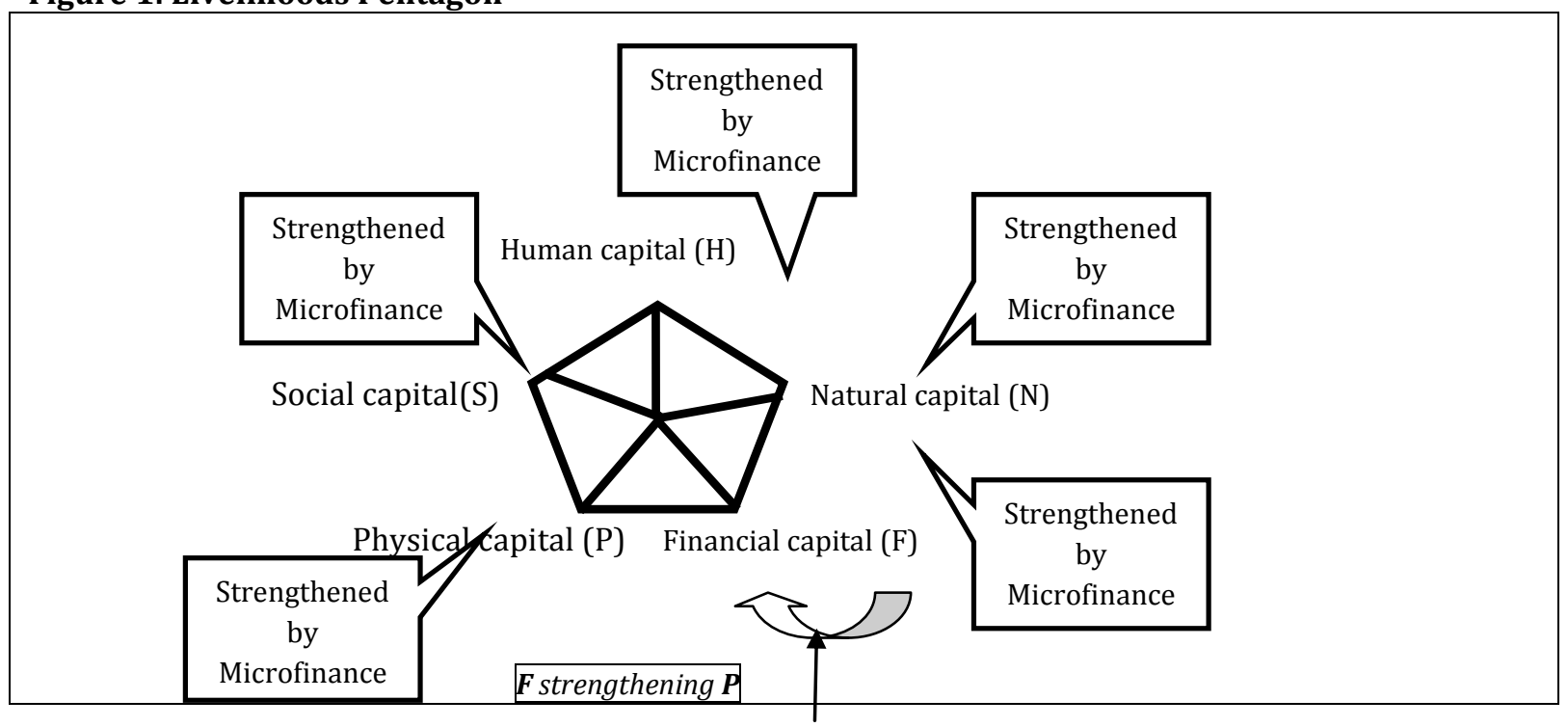

Source: Author's imagination (adapted from Carney's 1998 SL Framework)

Figure 2 above shows how microfinance plays the role of strengthening the rest of the livelihood assets for improved livelihood outcomes. The figure shows the support that the livelihoods require from microfinance for the promotion of livelihood opportunities. Livelihood strategies will then restore agency to poor people. As Rakodi (2002) puts it, the support of access to 'capitals' makes the poor to be active

\footnotetext{
${ }^{4}$ More examples were added.
} 
agents in coping with conditions, they are no longer regarded as passive victims of poverty. Access to finance by the poor will then enable them to have control over their assets and environment. As a result they become capable of defending themselves against impoverishment as they engage in coping strategies for their livelihoods. Access to finance makes them to engage in risky but potentially profitable economic activities that are likely to make them wealthy. The poor are thereby empowered to pull themselves out of poverty and the vicious cycle of poverty transforms to a virtuous cycle of positive livelihoods outcomes. The perceptions of the three categories of respondents show that on average, microfinance alleviates poverty. These perceptions were supported by the results that demonstrated a positive relationship between microfinance and welfare variables (assets, income and savings) hence the need for developing a link between microfinance and livelihoods.

\section{The New Model: Microfinance-Livelihoods Linkage Model}

New ideas have evolved for decades in an effort to alleviate poverty among the rural poor people. Currently, a number of development agencies are following the 'livelihoods approach' (Sa-Dhan, 2003). These are, among others, CARE International, UK DFID, Oxfam, World Bank, World Food Program (WFP) of the United Nations (UN), World Vision, Food and Agricultural Organization (FAO), Overseas Development Institute (ODI) and UNDP. As discussed earlier, the poverty lending and the financial systems perspectives do not provide for a linkage between microfinance and livelihoods. Since they are pre-occupied with money/credit for the poor, they have faced sustainability challenges. Though the financial systems approach aims at institutional sustainability, there are still challenges because the poor fail to access expensive sources of capital hence the poverty alleviation objective is jeopardized. On the other hand, the poverty lending approach is minimalist and this leaves a lot in terms of impact and sustainability. According to Sa-Dhan (2003), the minimalist approach to microfinance clearly cannot make a major impact on the lives of the people without taking into account their livelihoods. This paper therefore borrows heavily from the SLA so as to address sustainability issues that will help us to develop a hybrid model. The author refers to this thinking as the "Microfinance-Livelihoods model." It seeks to integrate microfinance with the livelihoods of the rural poor. A combination of the five capitals from the SLA with microfinance suggests an improvement of the welfare positions of individuals, households and communities.

Justification for the New Model: On one hand, microfinance is seen as an intervention for poverty alleviation and on the other, the sustainable livelihoods framework gives a clear presentation of the key factors that have an effect on the livelihoods of people. It also shows a relationship between them (DFID, 1999). Rural microfinance is a poverty alleviation strategy that focuses on development at grassroots level where the poor people are located. The poor should be afforded a chance to access financial resources for the management of their livelihoods. The sustainable livelihoods framework is also people centered, making it a framework that supports participatory development by allowing the poor to manage their livelihoods. Such similarities are striking. There is therefore need to identify a link between these two frameworks. The linking efforts by this study thereby propose the Microfinance-Livelihoods Model. The model combines microfinance with livelihoods so as to achieve both poverty alleviation and sustainability. A holistic approach to rural poverty alleviation is anticipated from this linkage.

Elements of the New Model: As shown in Figure 3 above, quadrant 1 depicts the elements of the PLA, quadrant 2 shows the FSA and 3 shows the elements of the SLA. The new model (quadrant 4) is therefore a hybrid of the positive elements from the three quadrants. The figure above lists the elements of the proposed model that aims to achieve poverty alleviation and sustainability in microfinance. The ML Model borrows from the strong elements of the SLA so as to propose the realization of sustainable interventions in microfinance. It is rather a hybridization of microfinance and sustainable livelihoods. Traditional microfinance models do not have a connection between microfinance and livelihoods. Lont and Horpse (2004) argue that a missed opportunity exists because of the lack of connection between microfinance and livelihoods. This paper therefore proposes to give a contribution to both microfinance and the livelihoods discourse. Hence, the proposal of an integration of the two fields of study into a hybridized model. Lont and Horpse further argue that for microfinance programs to be effective there is need to understand the livelihoods of participants. Complimentary roles exist between microfinance and livelihoods hence the need to put them together to achieve both poverty alleviation and sustainability. 
Since the microfinance-livelihoods model is about developing a strong link between microfinance and livelihoods, a strong linkage between microfinance and assets should be proposed. On the one hand, we note that rural people's livelihood strategies are based on the availability of assets. On the other hand, microfinance supports the concept of asset building that leads to wealth creation. Bringing the two together has got a potential to achieve both poverty alleviation and sustainability among the rural poor. Zoetelief (2004) strengthens this argument by stating that livelihoods and microfinance are not necessarily separate fields of activity since they complement each other. This complementarily needs strengthening by identifying the relationship between microfinance and livelihoods, hence the proposal for a microfinance-livelihoods model. The findings of this study established a significant and positive relationship between assets and microfinance. It is important to remember that in our context, assets provide a basis for the poor's livelihood strategies. Financial intermediation (in the form of microfinance) supports the livelihood strategies of the poor. This explains the need to have a strong relationship between the two fields of study (i.e. microfinance and livelihoods). Microfinance participants need to be in a position to track and analyze their standards of living. This understanding will help them to analyze assets availability and then identify appropriate livelihood strategies within the wider economic environment. The resultant model should be robust because of the combination of microfinance and livelihoods.

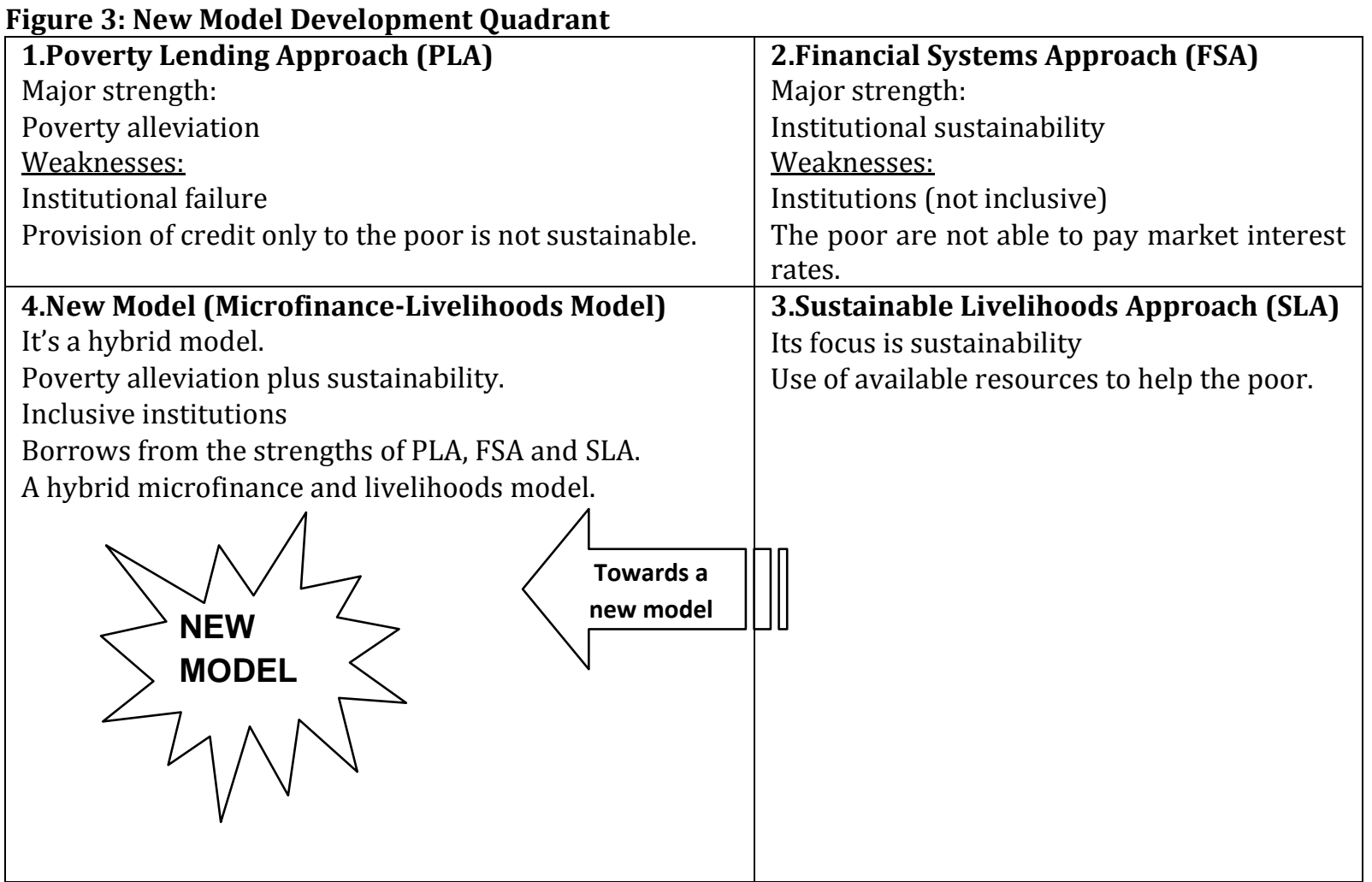

Source: Developed by Author

The Microfinance-Livelihoods Model's Answers to Frequently Asked Questions: A number of questions surround the traditional microfinance models. According to Krantz (2001), microfinance models have not answered the 'who are the poor?' question. Poverty should be explicitly defined and the poor should be located so that they benefit from the linkage. In many cases, the rural poor are further marginalized as the rural elites cause a 'crowding-out effect' on the available but meager rural resources. The rural elites have better access to resources than the poor. Microfinance calls for inclusive finance for the promotion of the livelihoods of the poor. Development agencies should take their time in identifying the poor. The new model attempts to put this question into focus. What are the social relations of poverty? Kratnz asserts that social relations of poverty have a strong influence on livelihoods transformation. Transformation would allow poor people to move from one livelihood to the next hence gaining ground towards the financial frontier. The new model then brings in the social relations aspect for livelihoods transformation through microfinance. 
Gender aspects should be taken into consideration. This will augur well with microfinance that favours more women than men. In all microfinance cases that are in literature, other empirical studies and our field findings, microfinance programs have between $75 \%$ and $95 \%$ female composition. Our research findings recorded $82 \%$ women in microfinance which approximates the international average. A strong linkage between microfinance and sustainable livelihoods will take care of the gender question. Capacity building is very imperative for the sustainability of poverty alleviation strategies. Institutions lack capacity to execute poverty alleviation programs. The new model, with its integrated approach, proposes that capacity building needs to be promoted through human capital development and institutional building. Institutional building is supported through the development of the 'five capitals' (natural, physical, human, finance and social). In Zimbabwe, the Southern Africa Microfinance and Enterprise Capacity Enhancement Facility (SAMCAF), an NGO, runs capacity building programs to strengthen microfinance institutions. The crisis situation in Zimbabwe weakened the organization as the country witnessed the withdrawal of the donor community. Investment in this area is desperately needed for the growth of the microfinance sector in Zimbabwe.

\section{Conclusion and Policy Implications}

The earlier models of microfinance have led to the split into poverty and sustainability camps. These two schools of thought have separate objectives that need to be combined. The new model endeavors to bring the two schools of thought together. Poverty alleviation is one of the painstaking objectives of governments but at the same time, the lack of sustainability in poverty alleviation programs has been notorious. It is therefore important to focus towards achieving poverty alleviation and sustainability. The Microfinance-Livelihoods Model takes advantage of a combination of microfinance and the sustainable livelihoods frameworks (see Figure 3 above for a summary). The components in the sustainable livelihoods framework are linked to one another, and interact in a constantly dynamic fashion. Bringing microfinance into the continuum strengthens the sustainable livelihoods framework hence increasing its dynamism as a poverty alleviation intervention. This will also strengthen the sustainability agenda in poverty alleviation as the poor sustainably realize livelihood outcomes. The linkage between livelihoods and microfinance benefits the poor through assets accession, valorization and transformation. Survey findings also established a strong relationship between microfinance and livelihood outcomes (assets, income and savings) hence the need for a strong linkage between them. The linkage was therefore proposed through the Microfinance-Livelihoods (ML) model.

\section{References}

Adams, D. W., Douglas, H. G. \& Von-Pischke, J. D. (1984). Undermining Rural Development with Cheap Credit. Boulder, CO: Westview Press.

Ahmed, S. (2010). Microfinance institutions in Bangladesh: achievements and challenges. Managerial Finance, 35(12), 999 - 1010

Birdsall, N. \& Londono, J. L. (1997). Assets Inequality Matters: An Assessment of the World Bank's Approach to Poverty Reduction. The American Economic Review, 87(2), 32-37.

Cahn, M. (2002). Sustainable Livelihoods Approach .Concept and Practice. Massey University. [Online] Available: www.devnet.org.nz/conf2002/papers. (June 13, 2009).

CAP Business Plan. (1999). Masvingo Credit against Poverty Business Plan. Masvingo Zimbabwe: CAP.

Carney, D. (1998). Implementing the sustainable rural approach'. In Carney, D., ed. 1998. Sustainable Rural Livelihoods: What Contribution Can We Make? (pp. 3-23). London: Department for International Development (DFID).

Chambers, R. (1983). Putting the last first. New York: Longman Inc.

DFID. (1999). Sustainable Livelihoods Guidance Sheets. [Online] Available: www.nssd.net/pdf/section.pdf (February 1, 2010).

Ellis, F. \& Biggs, S. (2001). Evolving themes in rural Development. Development Policy Review. United Kingdom: Overseas Development Institute (ODI).

Fouracre, P. (2001). Transport and Sustainable Rural Livelihoods. Rural Travel and Transport Program. TR Limited. [Online] Available: www.transport-links.org . (February 10, 2010).

Gulli, H. (1998). Microfinance and Poverty: Questioning the Conventional Wisdom. Washington D.C.: Inter-American Development Bank.

Hishigsuren, G. (2007). Evaluating Mission Drift in Microfinance: Lessons from Programs with Social Mission. Evaluation Review, 31(3), 203. 
Hussein, K. (2002). Livelihoods Approaches Compared: A Multi-Agency Review of Current Practice. London, UK: Department for International Development (DFID) and Overseas Development Institute (ODI).

Hussein, K. \& Nelson, J. (2004). Sustainable Livelihoods and Livelihood Diversification. IDS working paper 69. London, UK: Institute of Development Studies.

Krantz, L. (2001). The Sustainable Livelihoods Approach to Poverty Reduction: An Introduction. Sweden: SIDA.

Lont, H. \& Hospes, O. (2004). Livelihood and Microfinance: Anthropological and Sociological Perspectives on Savings and Debt. Amsterdam: Eburon Academic Publishers.

Moser, C. \& Dani, A. A. (2008). Assets, Livelihoods, and Social Policy. New Frontiers of Social Policy. Washington, DC: The World Bank.

Rakodi, C. (2002). A Livelihoods Approach: Conceptual Issues and Definitions. In Rakodi, C. and T. LloydJones, eds. 2002. Urban Livelihoods: A People Centered Approach to Reducing Poverty. London, Sterling: Earthscan.

Robinson, S. M. (2001). The Microfinance Revolution: Sustainable Finance for the Poor. Washington, D.C: The World Bank and Open Society Institute.

Robinson, S. M. (2002). The Microfinance Revolution: Lessons from Indonesia, 2. Washington, D.C: The World Bank and Open Society Institute.

Sa-Dhan, G. (2003). Sustainable Livelihoods and Microfinance. New Dehli, India: Sa-Dhan. Funded by Ford Foundation: www.sa-dhan.org. (Accessed 06 February 2010).

Sherraden, M. (1991). Assets and the Poor: A New American Welfare Policy. New York: M.E. Shape. Inc.

Solesbury, W. (2003). Sustainable Livelihoods: A Case Study of the Evolution of DFID Policy. Working Paper 217. London, UK: ODI.

Soussana, J., Blaike, P., Springate-Biginski, O. \& Chadwick, M. (2000). Understanding Livelihood Processes and Dynamics. Livelihood-Policy Relationships in South Asia, Working Paper 7. Leeds, UK: School of Geography.

Turton, C. (2000). The Sustainable Livelihoods Approach and Program Development in Cambodia. Working Paper 130. London, UK: Overseas Development Institute (ODI).

UNDP. (2008). Comprehensive Economic Recovery in Zimbabwe: A Discussion Document. Zimbabwe: UNDP.

Zhang, N. \& Wong, P. (2014). Sustainable Microfinance in Asia: Landscapes, Challenges and Strategies. Milken Institute.

Zoeteleif, J. (2004). Microfinance from Below: Exploring Rural Livelihoods in Tanzania. In Lont, H. and 0. Hospes, eds. 2004. Livelihood and Microfinance: Anthropological and Sociological Perspectives on Savings and Debt. Amsterdam: Eburon Academic Publishers. 